\title{
Mokhrenis - Monument of Early-Christian Architecture of Artsakh: Bases of the Formation of the Local School
}

\author{
Armen Kazaryan, ${ }^{1, *}$ \\ ${ }^{1}$ Scientific Research Institute of the Theory and History of Architecture and Urban Planning, Branch of the \\ Federal State Budget Institution "Central Scientific-Research and Project Institute of the Construction Ministry \\ of Russia”, Moscow, Russia \\ *Corresponding author. Email: armenkazaryan@yahoo.com
}

\begin{abstract}
The article reveals the peculiarities of a single monument of Armenian Early Christian architecture of the historical province of Artsakh, a part of the kingdom of Great Armenia, since the late fifth century — the Sassanid Marzpanate of Albania, and since the ninth-tenth centuries - of the Armenian kingdom of Khachen. This is a ruined church of the monastery of Okhta Drni, near the village of Mokhrenis (Mokhrenes), the Hadrut District of the Republic of Nagorno-Karabakh. This research develops the earlier formulated author's idea that the composition of this church of the type of tetraconch with corner niche was a result of simplification of a variant of the same type with four additional corner cameras which could be traced back to the samples of the central province of Armenia of the late sixth - early seventh centuries. Focal point of the article is at the stylistic peculiarities of architecture. Specific features of exedras - rounded in their exterior, and underdome pillars were connected with the provincial method of building of roughly cut stones. To find a place of this church in the medieval architecture of the Transcaucasian lands, the author offers some compositional analogues and describes the specifics of masters' work in Mokhrenis. The dating of the monuments to the last quarter of the seventh or early eighth century can be based on the analysis of the stone cutting of the imposts. As a conclusion, there is a characteristic of provincial architectural creativity in Artsakh, and the role of the church of Mokhrenis in that phenomenon.
\end{abstract}

Keywords: Mokhrenis, Artsakh, Medieval Armenian architecture, Eastern Christianity, Tetraconch church.

\section{INTRODUCTION}

Among numerous monuments of Armenian Early Christian architecture there are rare very unusual constructions, which dating and origin inspirate scholars' high interest. Some of them situate in the mountains of the historical province of Artsakh, a part of the kingdom of Great Armenia, since the late fifth century - the Sassanide Marzpanate of Albania, and since the ninth - tenth centuries - of the Armenian kingdom of Khachen.

*Fund: This study is based on the research, supported by the Program of Fundamental Research of the Russian Academy of Architecture and Construction Sciences and of the Ministry of Construction, Housing and Utilities of the Russian Federation 2021 .
Now, the main part of the province is located on the territory of the Republic of Nagorno-Karabakh or Artsakh; the monument in question is situated, however, in $3.5 \mathrm{~km}$ to the north-west from the village of Mokhernis (Mokhrenes), the Hadrut District of the Republic, and, in the course of the recent war, in the autumn of 2020, it happened to be in the zone of the Azerbaijan control. The war strengthened the wary of specialists in the sphere of protection of historical heritage about the destiny of ancient constructions - especially, taking into account the sad picture of the total destruction of the Armenian heritage in the Nakhichevan Region of the Republic of Azerbaijan in the 2000s. Not less dangerous is declaring churches of the region as 'Albanian' ones, with the following 
misrepresentation of their historical outlook testifying their Armenian origin. Beside the written sources, there are architectural monuments which give us the truth on the process of cultural development of the region. That is why the research of these monuments is of special importance including the field studying of the monument and its analysis based on such practical studies.

Ruined church and other constructions of the monastery of Okhta Drni are situate on the wooded slope of the mountain of Yughusen. According a legend, the name of the monastery of 'Seven Doors' was connected with the veneration of seven brothers died for the sake of the freedom of their motherland. The construction of the church was assigned to their sister. There is a specially venerated sacred space near the monastic water source - the Sister's Tomb [1]. The monastery of Okhta Drni has a long history of development, testified with two khachkars near the church and dated to 997 and 1044.

Picturesque ruins of the monastery have been fixed since the late nineteenth century [2]. Its secondary finding was made by the expedition of $\mathrm{S}$. Karapetyan [3]. A more detailed analysis of the church was made in articles and a monography by M.M. Hasratyan, in other publications [4], [5], [6], [7], [8]; a reconstruction of the façade was done in a book by T. Marutyan [9], and a reliable plan is in a book by Sh. Mkrtchyan [10]. In 1987, together with S. Karapetyan, I checked the measurements of the church cross sections, also we measured three blocks of imposts [11], [12]. The architecture of Mokhrenis was studied also by A. Plontke-Luning [13] and P. Donabedyan [14].

The dating of Mokhrenis differs in the interval of the fifth-seventh centuries. Anyway, there is a general agreement that the church was built in the period of inclusion of two Armenian provinces, Artsakh and Utik, into the Marzpanate (province) of Aghvank or Albania of the Sassanid Iran. But we should remember, that the legal status of the central Artsakh in the Classical epoch was not one and the same. In 571, having refused to join the antiSassanid rebellion, Syunik Prince Vahan left the Armenian Marzpanate. As a single shahr, Syunik submitted to the Vice-Shah of Iran, settled in Gandzak. As a result, Artsakh was given to Syunik; the fortress of Derbent and the Chor Pass were also under the control of the prince of Syunik. Such situation existed till 640. At that, the district of Mius Haband of Artsakh was a centre of the Sunik princes and was called also Sissakan-i-Kotak (i.e. Small Syunik) [15]. Mokhrenis is located by the ancient administrative centre of Mius Haband the unassailable fortress of Ktysh: as early as in the pre-Arabic times, there was the famous monastery of Gtych founded lower (The Cathedral was constructed in 1241-1248).

Main attention of the article is centred at the stylistic peculiarities of architecture of the Mokhrenis church in the context of provincial building technic. To establish the place of that church in medieval architecture of Transcaucasia, compositional analogies are presented, there is a comparative analysis of the stone carving on the imposts, and and the dating is checked.

\section{DESCRIPTION OF THE MONUMENT, AND THE LEVEL OF ITS PRESERVATION}

Being located on a mountain slope, the church is based on a specially built platform, the eastern side of which is raised above the ground level on 3 $\mathrm{m}$ approximately. The retaining wall smoothly passes into the wall of the altar apse - so, from the bottom of the hill, the building created a strong impression in the time of its complete preservation ("Figure 1").

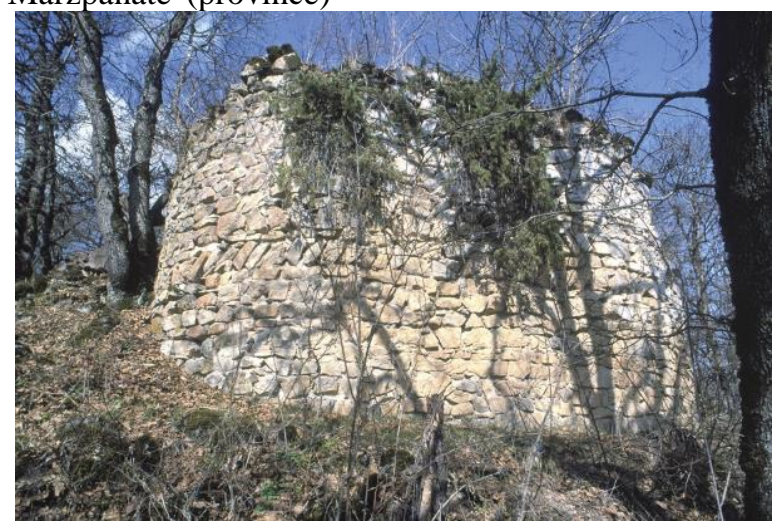

Figure 1 Mokhrenis. Exterior from SE by S. Karapetyan, 2011. 
The monument of Mokhrenis belongs to a rare architectural type of tetraconch with corner niches, with the absence of additional cameras. In other words, the entire composition is shaped exclusively with eight alternating large and small exedrae. The latter ones are commonly referred in special literature as corner niches ("Figure 2").

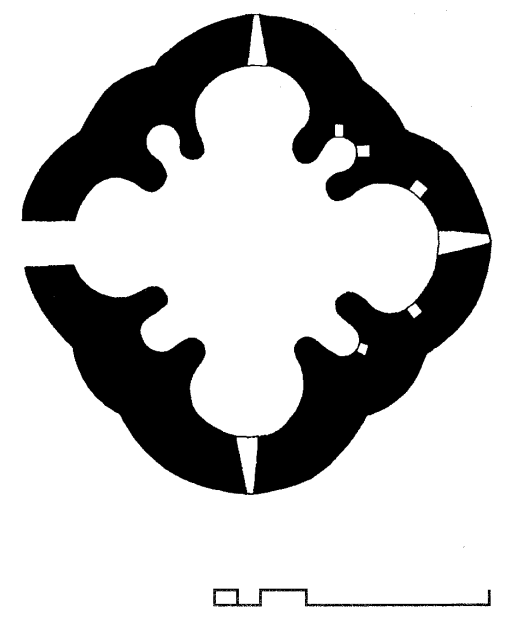

Figure 2 Mokhrenis. Plan. Measurements by S. Karapetyan and A. Kazaryan, 1987.

Internal axial dimensions of the church are almost one and the same, about $8 \mathrm{~m}$. All large exedrae, located on the main axis of the building, are also of the same size (the width of the altar one is about $2.8 \mathrm{~m}$; the average width of others is $2.5 \mathrm{~m}$ ) and of the horseshoe-shaped plan (according to Hasratian, the omega shape). The corner niches were also of the same plan (average width $0.8 \mathrm{~m}$ ). The contour of the walls of the exedrae and niches smoothly passes into a rounded silhouette of eight underdome pylons. Inspection of the real plan reveals a rather loose nature of the drawing of the contour of the walls. Only the basic dimensions were fixed, but even such measurements as the width of the openings of the niches or the width of the pylons vary obviously.

The exedrae and niches were covered with conchs, shaped toward the central space with wide arches. The vertical cross section of the conchs is horseshoe-shaped. Through four large and four small, diagonally set and obviously horseshoeshaped arches, those pylons carried the now-lost dome (span $3.9 \mathrm{~m}$ on the north-south axis, $3.7 \mathrm{~m}$ on the west-east axis). The shape of the underdome passage and the dome are unknown because of the bad state of preservation of the monument ("Figure 3").
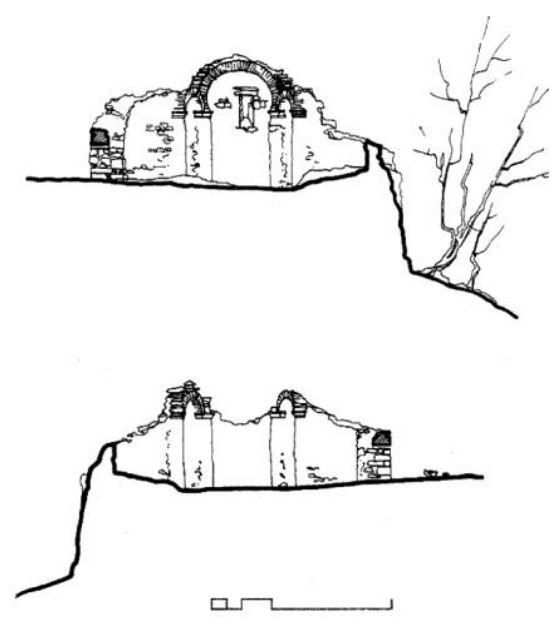

Figure 3 Mokhrenis. Sections of the tetraconch on the east-west axis. Measurements by S. Karapetyan and A. Kazaryan, 1987. 
Only the northern exedra is preserved now, and the eastern and southern ones are preserved only partially. The height of the wall of the western exedra is limited with the entrance lintel. The corner niches are preserved completely. Judging by the outlook of the ruins, the church has never been restored for many centuries ("Figure 4").

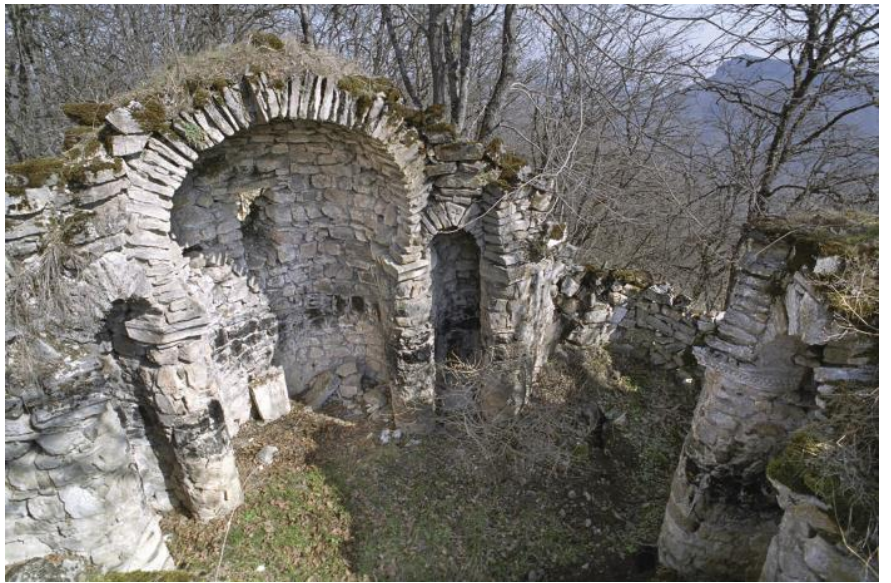

Figure 4 Mokhrenis. Interior view looking NE. Photographs by S. Karapetyan, 2011.

From outside, the contour of the wall is created with concentric curves. It allows to expose all the components of the inner composition from the outside. The eight-loped structure of the monument resembles a rosette [16]. The walls of the exedrae are about $1.05 \mathrm{~m}$, and those of the corner niches are $1.35 \mathrm{~m}$. Due to this, the external volumes of the niches are more impressive than they would be with the same thickness of the walls as the exedrae. Thus, the axial dimensions of the church are approximately equal, about $10.10 \mathrm{~m}$.

Assumption about the existence of a drum, octahedral from the outside, put forward on the basis of the number of the internal pylons [17], seems admissible. However, there might not have been any relationship between those two factors. If we proceed from analogies with monuments that had externally semicircular exedrae (for example, Tsrviz, or Moro Dzoro), then a cylindrical drum should be restored in Mokhrenis as well. This form is shown on the reconstruction by $\mathrm{T}$. Marutyan [18].

Many inaccuracies in the plan drawing and even some architectural forms can be explained with peculiarities of provincial construction methods. The masonry of the monument is traditional for medieval Armenian buildings, but, unlike its typical variety, here the outer layers of the masonry are composed of roughly cut, almost chipped pieces of basalt. On the surface of the walls, wide rows of large stones alternate with narrow rows of tiles similar to plinth, but this principle is not kept consequently. All the arches are laid of the same flat chipped stones $[19,20]$; the locking elements of the arches are made of triangular prisms of stone. The church entrance, $1.06 \mathrm{~m}$ wide, arranged in the western exedra, as well as the only preserved window opening in the northern arm are covered with stone beams. From the inside the walls were plastered.

\section{IMPOSTS OF THE UNDERDOME PYLONS}

The only purely cut elements are the imposts under the arches. Their planned shape is faceted but corresponds to the bend of the pylons. In the most developed version, the imposts are presented under the triumphal arch of the altar apse. There the lower rounded line outlines the boundaries of the pylon, and the upper one, faceted, subordinates to the heels resting on the block of arches. It is essential that the face of the block oriented to the underdome space corresponds to the frontal side of the large arches, while the heels of the small arches are cut off by the large arches. The profile of the six imposts consists of a smoothly rising straight fillet topped with a narrow flange.

The imposts near the apse look more complicated; they can be considered as capitals [21]. Having generally the same structure, they contain a strip of three narrow bands, a row of small dental, a row of beads over it, and a broader horizontal convex rod. The beads are set in the chess order to dentals and have tiny depressions in the mid of them, like slightly drilled dots. The extended surface of the elements is not vertical, but inclines towards the top ("Figure 5" and "Figure 6"). 


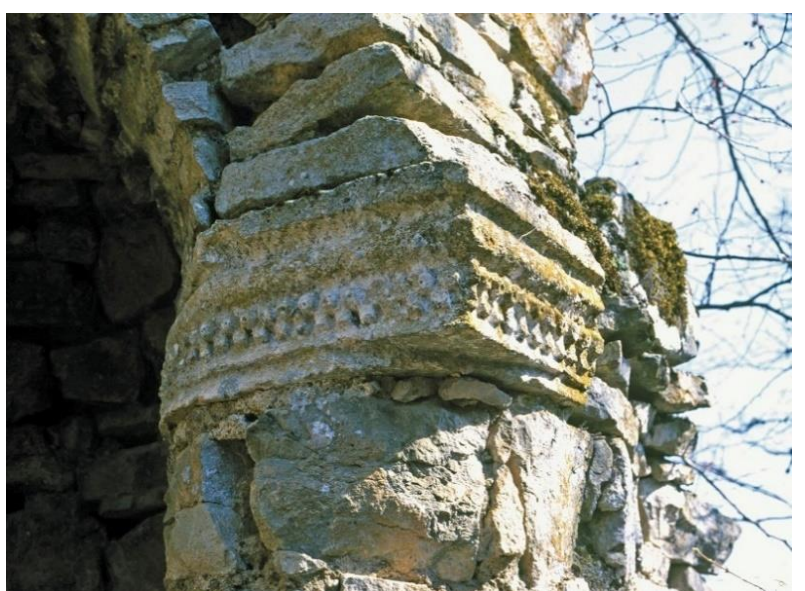

Figure 5 Mokhrenis. The northern impost of the apse. Photographs by S. Karapetyan, 2011.
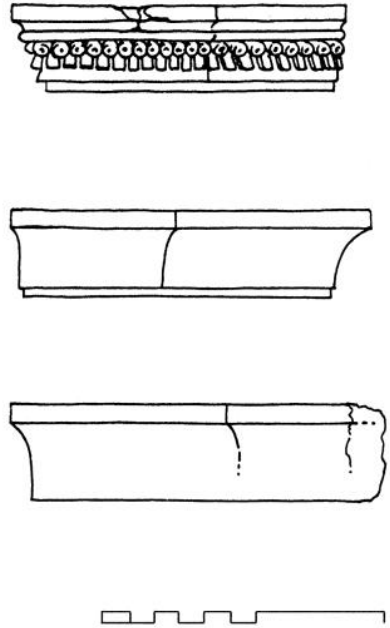

Figure 6 Mokhrenis. The southern impost of the apse; the imposts of the northern exedra. Measurements by A. Kazaryan, 1987.

\section{DATING OF THE MONUMENT, AND ITS PLACE IN THE ROW OF SAME-TYPE BUILDINGS}

The first researchers of the church attributed it to the fifth-sixth centuries and considered its composition as a prototype for tetraconchs with corner niches [22, 23]. T. Marutyan contradicted this opinion: he based on the hypothesis of the origin of corner niches as elements providing passage to corner cameras and took Mokhrenis for a simplified version of a same-type composition with corner cameras [23].

Simple compositions could be created both at the dawn of the evolution of a certain architectural type and much later - due to the process of simplification of complicated structures. Taking into account the provincial character of Mokhrenis, and the fact that its masters followed well-known samples, not inventing something original, the second option is more justified. Otherwise, it is difficult to believe in the possibility of adopting a provincial form of the plan as a basement for construction of the most important churches of the Armenian Catholicoses - John Bagarantsi, the builder of the Avan Cathedral (690-s), and Komitas, the builder of the St Hripsime Church in Vagharshapat (613).

An appeal to all the row of tetraconchs with corner niches clearly shows the concentration of churches with corner cameras in the centre of the country; at that, on the periphery, more than a half of similar monuments have either only two eastern cameras, i.e. pastophorion aside the apse (the 
seventh-century churches of Artsvaber and Soradir, the church in Aghtamar island, 915-921; all in Vaspurakan province), or have no additional cameras (the only example of Mokhrenis). If we take into account similar monuments of Eastern Georgia, the architecture of which developed in close interaction, even in unity with Armenian one, we find two churched without additional cameras. Both are located in province, in Kakheti. There are churches in the monastery of Dzveli Shuamta and of the fortress of Kvetera (possibly, 10th cent.); on the common opinion of researchers, their compositions are simplifications of Georgian versions of more complicated tetraconchs with corner niches, originating from Jvari in Mtskheta (640-s). Therefore, the composition of the church in Mokhrenis, shaped in the periphery, should be considered as a secondary one. However, it was not mediocre; it was a new word, a new interpretation of the known scheme - possibly famous by the time of building that monument in Artsakh.

An archaic feature was considered to be the rounded external shape of the exedrae of the monument in question, that shape which makes the building eight-loped, with alternation of small and large petals [24]. In domed churches of provincial Armenian architecture, such a principle of external representation of exedrae is known, for instance, in the tetraconch of Tsrviz, or in the church of the Moro Dzoro Monastery (7th cent.), in the tetraconch of Sbkhech in Tayk (7th cent.), and in the threeconch church of Surb Astvatsatsin or Surb Karapet in Til (7th -10 th cent.). In Georgian architecture, it was typical for tetraconchs of Kakheti: Ninotsminda (not earlier the 11th cent.), and in the monastery of Dzveli Gavazi (possibly, 7th cent.) [25]. Noteworthy, all these buildings are monuments of provincial architecture, where they used roughly cut stones in the masonry.

The secondary nature of Mokhrenis in comparison with classical samples of tetraconchs with corner niches one can judge on the shape of its pylons and imposts. The architectural fashion or some peculiarities of the construction technique prompted its builders to use rounded pylons, but the compositional idea with the square basement of the central space taken from the similar model forced the builders to change the planned form of the blocks of imposts, rounded in their lower part and faceted in the upper one, for the sake of creation of the square underdome base at least in the upper zone of the church.
A search for rounded forms similar to the pylons of Mokhrenis leads us, first of all, to a group of Armenian monuments of the middle and the second half of the seventh century, from which the underdome pylons with a quarter-circle, semicircle, or three quarters of a circle cross section originated (Agarak, Zvartnots, Arutch, Soradir, the cathedral of Artik, etc.).

M.M. Hasratyan especially noted the roll call of the combination of beads and dentals on the imposts of Mokhrenis with ornaments framing the southern entrance of the Yeghvard Basilica [26]. In connection with the analogues of the Mokhrenis stone carving, it is necessary to take into account the real dating of the Yeghvard Basilica in 660 [27], as well as the presence of beads with 'dimples' on the carved stucco decoration of the church of the Sudagylan complex near Mingechaur of 640 [28], and on the same decoration of the Patriarchal Palace in Dvin, 640-s [29], which relate with the examples of the Sassanian stucco tradition [30]. Such beads were used to create six-petal flowers in the middle field of intertwined rings on the slabs of the chancel screen of the Zvartnots Church (641661 ); 'dimpled' beads were used in the decoration of the late seventh-century Ateni Zion, namely on the relief image of the Senmurv and on the costumes of some characters. The balls with dimples in the middle of the ornamental rim of one of the round windows of Zvartnots look slightly larger than all these samples [31].

Monuments of the late sixth - early seventh centuries (Avan, Hripsime), as well as later ones, up to the second half of the seventh century (Sisavan) contain numerous samples of rows of small dentals, close to the elements of the capitals of Mokhrenis.

All this allows us to attribute the monument to the time not earlier than the mid seventh century. It is also necessary to take into account the time of construction of the geographically most closely located church of the same type, created in the classical tradition and closely following the forms of the St. Hripsime Church. This is the Sisavan Cathedral in Syunik, created, judging by the ornamental details and signs of its masters, by builders arrived from the central regions of Armenia [32]. It is possible to assume that the local, Artsakh craftsmen, who erected Mokhrenis, turned to the majestic Sisavan. The carved decoration of Mokhrenis reflects the ornaments of the window sills of another largest monument in Syunik - the Tsitsernavank Basilica, located on the very border 
with Artsakh. I am inclined to date this basilica, like Mokhrenis, to the second half of the seventh century [33].

At the same time, the later creation of Mokhrenis cannot be excludes - particularly, in the tenth - the first half of the eleventh centuries, when Artsakh was a part of the kingdom of the Armenian Bagratids, and when the traditions of the seventh century were revived in Armenian architecture. Dating to the post-Arabic time can be based on such features of the composition of the church as the complete centricity of the plan with setting the corner niches exactly on the diagonal axes, and the absence of the difference of two pairs of exedrae typical for the seventh century. And yet there are more reasons for attributing Mokhernis to the preArabic epoch.

\section{CONCLUSION}

When Artsakh and Utik (Eastern Territory of Armenia) were included by Sassanian Iran into the Mazpanate of Albania (Aghvank; Caucasian Albania), formed earlier on the basis of the Late Antique kingdom of the same name, they involuntarily found themselves in a new political orbit. Very soon, the political and religious centres of that enlarged Iranian province moved from the Albanian to the Armenian part. The cultural and religious domination of Armenians from the sixth century, which had its foundations since the Christianization of the Kura Valley and the territory eastward of it, up to modern southern Dagestan, quite firmly determined the orientation of all Christian peoples of those territories towards the Armenian Church and its value. It was facilitated by the involvement of Syunik in the political life of Artsakh and even the Caspian territories. That is why, both on the territory of the former ancient kingdom of Albania, and in the Armenian provinces docked with it by the Sassanian power, one can find many architectural compositions and combinations of architectural forms, which are modifications of the compositional ideas and forms from central Armenia. The church architecture of the two parts of the Aghvank Region - Albanian or old one, and Armenian or new one - is united only by their provinciality, which lies in the wide usage of simplified forms and the construction techniques with roughly cut and chipped stone blocks, cobblestones, as well as in the obvious conservatism of ideas.

However, sometimes the most ambitious projects were implemented in simplified and rough forms. The Albanian church of Lekit in the foothills of the Caucasian Ridge, for instance, reproduced the compositional idea of the Zvartnots Church in provincial technique, in half of the original size and with thickening of structures. A system of thin pilasters set apart from each other shaped a simplified version of the architectural order [34]. Sometimes, provincial masters seriously modified the artistic image connected with similar 'classical' samples. So, the inner and outer walls of Mokhernis acquired rounded shapes, and its inner perimeter turned out to look as a continuous wavy line. The Mokhernis Church serves a vivid example of talented architectural creativity in the province, located far from the central phenomena of development of Armenian architecture.

\section{AUTHORS' CONTRIBUTIONS}

This paper is independently completed by Armen Kazaryan.

\section{REFERENCES}

[1] Sh. Mkrtchyan, Historical-architectural monuments of the Nagorno-Karabakh (Istoriko-arkhitekturnye pamiatniki Nagornogo Karabakha), Parberakan, Yerevan, 1989, p. 71 [in Russian].

[2] Makar arch, Barkhudariants, Artsakh (Artsakh), Aror, Baku, 1895, p. 78 [in Armenian].

[3] Sh. Mkrtchyan, R. Abgaryan, S. Karapetyan, The monastery 'Okhte Drni' in Mokhrenis (Mokhrenisi 'Okhte Drni' vanke), Etchmiadzin, no. 11-12, 1982, pp. 46-50 [in Armenian].

[4] M. Hasrat ${ }^{\text {yan, Tetraconch with corner niches }}$ of Mohrenis (La tétraconque a nishes d'angle de Moxrenis), Revue des études arméniennes T. XXI (1988-1989) 365-384 [in French].

[5] M. Hasratian, Artakh school of Armenian architecture (Haikakan tcartarapetutian Artsakhi dprotse), Academy of Sciences of Armenia, Yerevan, 1992, pp. 25-28 [in Armenian].

[6] M. Hasratian, Early Christian architecture of Armenia, Incombook, Moscow, 2000, pp. 68, 300 .

[7] P. Cuneo, Moxrenis, Oxtэ Drne Vank, in: P. Cuneo, Armenian architecture from the fourth 
to the nineteenth century (Architettura Armena dal quarto al diciannovesimo secolo), Roma, 1988, p. 428 [in Italian].

[8] P. Cuneo, M. Lala Comneno, S. Manukian, Gharabagh (Documenti di architettura Armena, 19), OEMME edition, Milano, 1988, pp. 51, 84 [in Italian].

[9] T. Marutyan, Architectural monuments (Arkhitekturnye pamiatniki), Khorhurdayin Grogh, Yerevan, 1989, pp. 106-109, fig. 626627 [in Russian].

[10] Sh. Mkrtchyan, Historical-architectural monuments of the Nagorno-Karabakh (Istoriko-arkhitekturnye pamiatniki Nagornogo Karabakha), Parberakan, Yerevan, 1989, pp. 71-75 [in Russian].

[11] A. Kazarian (A.Yu. Ghazarian), Tetraconches with corner niches: Functions and symbolism, Acts, 18th International Congress of Byzantine Studies. Selected Papers: Main and Communications (Moscow, 1991), I. Sevchenko, G. Litavrin, W.K. Hanak (Eds.), vol. III, Byzantine Studies Press, Shepherdstown, WV, 1996, p. 432, fig. 3c.

[12] A. Yu. Kazaryan, Church Architecture of the 7th Century in Transcaucasian Countries: Formation and Development of the Tradition (Tserkovnaia arkhitektura stran Zakavkaz'ia VII veka: Formirovanie i razvitie traditsii), vol. 4. Locus Standi Publ., Moscow, 2013, pp. 40-48, fig. 2496-2504 [in Russian].

[13] A. Plontke-Lüning, The Early Christian architecture of Caucasus. Development of Christian ecclesiastical construction in Lazica, Iberia, Armenia, Albania and the border regions, from the $4^{\text {th }}$ to the $7^{\text {th }}$ cent. (Frühchristliche Architektur in Kaukasien. Die Entwicklung des christlichen Sakralbaus in Lazika, Iberien, Armenien, Albanien und den Grenzregionen, vom 4. bis zum 7. Jh.), Verlag der Österreichischen Akademie der Wissenschaften, Wien, 2007, kat. s. 220-221, taf. 155.4-6 [in German].

[14] P. Donabédian, The Golden age of Armenian architecture of the $7^{\text {th }}$ century (L'âge d'or de l'architecture arménienne VIIe siècle), Parenthèses, Marseille, 2008, p. 82, fig. 146147 [in French].
[15] S. Eremyan, Armenia on 'Ashkharatsuits' (Haiastane est 'Ashkharatsuitsi), Academy of Sciences of Armenia,Yerevan, 1963, p. 70 [in Armenian].

[16] M. Hasratian, Artakh school of Armenian architecture (Haikakan tcartarapetutian Artsakhi dprotse), Academy of Sciences of Armenia, Yerevan, 1992, p. 26 [in Armenian].

[17] Ibid., p. 23.

[18] T. Marutyan, Architectural monuments (Arkhitekturnye pamiatniki), Khorhurdayin Grogh,Yerevan, 1989, p. 106 [in Russian].

[19] M. Hasratian, Artakh school of Armenian architecture (Haikakan tcartarapetutian Artsakhi dprotse), Academy of Sciences of Armenia, Yerevan, 1992, p. 25 [in Armenian].

[20] M. Hasrat ${ }^{e}$ yan, Tetraconch with corner niches of Mohrenis (La tétraconque a nishes d'angle de Moxrenis), Revue des études arméniennes T. XXI (1988-1989) 367 [in French].

[21] M. Hasratian, Artakh school of Armenian architecture (Haikakan tcartarapetutian Artsakhi dprotse), Academy of Sciences of Armenia, Yerevan, 1992, p. 27 [in Armenian].

[22] Ibid., p. 27; M. Hasrat ${ }^{`}$ yan, Tetraconch with corner niches of Mohrenis (La tétraconque a nishes d'angle de Moxrenis), Revue des études arméniennes T. XXI (1988-1989) [in French].

[23] T. Marutyan, Architectural monuments (Arkhitekturnye pamiatniki), Khorhurdayin Grogh,Yerevan, 1989, p. 108 [in Russian].

[24] M. Hasratian, Artakh school of Armenian architecture (Haikakan tcartarapetutian Artsakhi dprotse), Academy of Sciences of Armenia, Yerevan, 1992, p. 27 [in Armenian].

[25] Cuneo, Architettura Armena, 1988 [in Italian].

[26] M. Hasratian, Artakh school of Armenian architecture (Haikakan tcartarapetutian Artsakhi dprotse), Academy of Sciences of Armenia, Yerevan, 1992, p. 27 [in Armenian].

[27] A.Yu. Kazaryan, Church Architecture of the 7th Century in Transcaucasian Countries: Formation and Development of the Tradition (Tserkovnaia arkhitektura stran Zakavkaz'ia VII veka: Formirovanie i razvitie traditsii), vol. 2, Locus Standi Publ., Moscow, 2012, pp. 623-635 [in Russian]. 
[28] M. Useynov, L. Salamzade, History of architecture of Azerbaijan (Istoriia arkhitektury Azerbaidzhana), Gosstroiizdat, Moscow, 1963, fig. 27 [in Russian].

[29] K. Ghafadarian, Citi of Dvin and its excavations (Dvin k'aghak'e ev nra peghumnere), vol. 1. Academy of Sciences of Armenia, Yerevan, 1952, fig. 89 [in Armenian].

[30] A. Kazaryan, L. Mikayelyan, Architectural Decorations of Armenian Churches of the $7^{\text {th }}$ and the $10^{\text {th }}-11^{\text {th }}$ centuries and Their Presumably Sasanian Sources, in: Sasanian Elements in Byzantine, Caucasian and Islamic Art and Culture, F. Daim, N. AsutayEffenberger (Eds.) (Byzanz zwischen Orient und Okzident, vol. 15), Propylaeum, Heidelberg, 2020, fig. 10. DOI: https://doi.org/10.11588/propylaeum.655

[31] S.Kh. Mnatsakanian, Zvartnots and same-type monuments (Zvartnotse ev nuinatip hushardzannere), Academy of Sciences of Armenia, Yerevan, 1971, fig. 17 [in Armenian].

[32] A.Yu. Kazaryan, Church Architecture of the 7th Century in Transcaucasian Countries: Formation and Development of the Tradition (Tserkovnaia arkhitektura stran Zakavkaz'ia VII veka: Formirovanie i razvitie traditsii), vol. 3, Locus Standi Publ., Moscow, 2012, pp. 124-145 [in Russian].

[33] Ibid., vol. 4, 2013, pp. 81-112 [in Russian].

[34] A. Kazaryan, Albanian church in Lekit and its place in the architecture of Transcaucasian countries (Albanskaia tserkov' v Lekite I ee mesto $\mathrm{v}$ arkhitekture stran Zakavkaz'ia), in: A.K. Alikberov, M.S. Gadjiev (Eds.), Albania Caucasica, vol. 1, Institute of Oriental Studies, Moscow, 2015, pp. 240-253 [in Russian] 